\title{
ВЫПУСКНИКИ-ГЕОЛОГИ ВОРОНЕЖСКОГО ГОСУДАРСТВЕННОГО УНИВЕРСИТЕТА В ГЕОЛОГИЧЕСКОМ ИНСТИТУТЕ КОЛЬСКОГО ФИЛИАЛА АН СССР - КОЛЬСКОГО НАУЧНОГО ЦЕНТРА РАН
}

\author{
П. В. Припачкин, П. К. Скуфьин
}

Геологический институт ФИЦ Кольского научного центра РАН, г. Апатиты

Поступила в редакцию 28 ноября 2019 г.

\section{GRADUATES-GEOLOGISTS OF THE VORONEZH STATE UNIVERSITY AT THE GEOLOGICAL INSTITUTE OF THE KOLA BRANCH OF THE USSR ACADEMY OF SCIENCES - KOLA SCIENCE CENTER RAS}

\author{
P. V. Pripachkin, P. K. Skufin \\ Geological Institute of the Kola Science Center of the \\ Russian Academy of Sciences (GI KSC RAS), Apatity
}

Received 28 November 2019

\begin{abstract}
В начале статьи мы хотели бы подчеркнуть - речь в ней пойдет исключительно о геологах-выпускниках ВГУ, работавших в заполярной науке, т.е. в Кольском филиале Академии наук СССР (КФАН СССР), затем - Кольском научном центре - КНЦ АН СССР (с 1990 г.), Российской Академии наук - КНЦ РАН (с 1991 по 2016 гг.) и, наконец, Федеральном исследовательском центре - ФИЦ КНЦ РАН (с 2017 г.). И даже ещё более конкретно - в Геологическом институте КФАН/КНЦ РАН (далее - ГИ КФАН/ГИ КНЦ). Вместе с тем, помимо других институтов нашего научного центра (где реже, но тоже встречались выпускники геолфака ВГУ), в Мурманской области существует немало производственных организаций (горно-обогатительные комбинаты, геологоразведочные экспедиции, тресты инженерно-строительных изысканий и т.д.), в которых также трудились и трудятся выпускники нашего замечательного факультета. Например, в 80-е годы XX века пост главного геолога Оленегорского ГОКа занимал Олег Эдуардович Извеков - выпускник геологического факультета ВГУ 1979-80 гг., сын Эдуарда Петровича Извекова - долгое время главного геолога
\end{abstract}

объединения «КМА Руда» (также выпускника геолфака ВГУ). Примерно в это же время в ЦентральноКольской геологоразведочной экспедиции (ныне ОАО ЦКЭ) работали ещё один наш выпускник Леонид Сергеевич Молотков (выпуск 1981 г.), сын другого известного воронежского выпускника - многолетнего главного геолога ЮВГРП - Сергея Петровича Молоткова. В Мурманской геологоразведочной экспедиции (ныне - АО МГРЭ) трудился Сергей Васильевич Жабин (выпуск 1982 г.), ставший впоследствии начальником Управления по недропользованию Мурманской области. Начальником информационновычислительного центра ОАО Кольского геологического информационно-лабораторного центра длительный период являлась Глазнева (Ледовская) Нина Сергеевна, выпускница (1972 г.) кафедры геофизики геолфака ВГУ. И этот ряд может быть существенно дополнен сотрудниками различных организаций из других городов Мурманской области. Однако это является отдельной и большой темой самостоятельного исследования, выходящего далеко за пределы настоящей публикации.

(C) Pripachkin P. V., Skufin P. K., 2019 
Что же касается собственно сотрудников КФАН СССР (ныне - ФИЦ КНЦ РАН), расположенном в очень уютном городке Апатиты, то следует сделать одну важную оговорку. В Геологическом институте, помимо научных сотрудников, ещё с советских времён работал обширный лаборантский корпус. Как правило, поставщиком таких сотрудников (имеющих среднетехническое образование) являлся известный на всю страну Кировский горный техникум. Техникум готовил очень приличных специалистов-геологов, однако, для дальнейшей научной карьеры им было необходимо получить высшее образование. В силу различных обстоятельств (работа, семья, дети) такое образование удобнее было получать заочно. Надо сказать, что в крупных геологических ВУЗах европейской территории нашей страны (Ленинградский университет и Горный институт, МГУ, МГРИ и т.д.) заочных отделений на геологических факультетах тогда не было. И здесь очень выручал Воронежский университет, имевший такую форму обучения. Поэтому едва ли ни девять десятых бывших лаборантов Геологического института, заочно получили высшее образование на геологическом факультете ВГУ! Естественно, перечислить их всех в рамках одной небольшой статьи не представляется возможным.

А рассказ о выпускниках дневного отделения геолфака ВГУ, работавших в ГИ КФАН СССР (КНЦ и ФИЦ КНЦ РАН) следует начать с двух выдающихся личностей - Александра Васильевича Сидоренко и Митрофана Степановича Точилина.

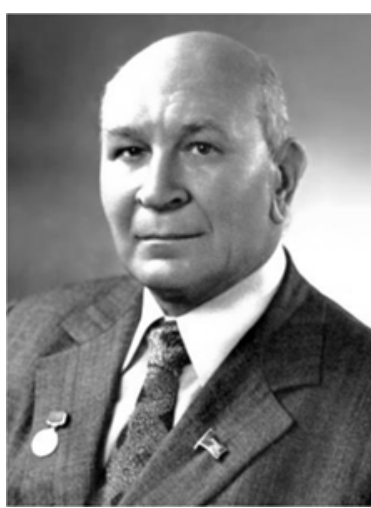

Сидоренко Александр Васильевич
Александр Васильевич Сидоренко (19171982) закончил геологический факультет ВГУ в 1940 г. прямо перед началом Великой Отечественной войны. По окончании учёбы был оставлен ассистентом при кафедре минералогии, поступил в аспирантуру. С началом Великой Отечественной войны А. В. Сидоренко ушёл на фронт. После участия в обороне Сталинграда, лечения в госпитале после полученных тяжёлых ранений и кратковременного преподавания в 1-м Ленинградском артиллерийском училище им. Красного Октября, в 1943 г. он был демобилизован и направлен в Туркменский филиал АН СССР, где работал до 1950 г. сначала старшим научным сотрудником, затем заведующим отделом полезных ископаемых Геологического института. В 1945 году он защитил кандидатскую диссертацию «К минералогии и геохимии жильных месторождений Копетдага».

В 1950 г. по предложению Президиума АН СССР А. В. Сидоренко был назначен заместителем председателя Президиума Кольского филиала АН СССР в
Апатитах, в 1952 г. стал председателем Президиума филиала. В 1951 году в составе филиала был создан Геологический институт, директором которого в 1955-1959 гг. был А. В. Сидоренко. За 12-летний период руководства Кольским филиалом АН СССР А. В. Сидоренко провёл огромную научно-организационную работу по созданию сети научно-исследовательских институтов, развитию комплексных исследований природных ресурсов Мурманской области, решению крупных народнохозяйственных проблем. Были развёрнуты комплексные научные исследования геологии и полезных ископаемых в малоизученных центральном и восточном районах Кольского полуострова, организована на месте разработка методов добычи, обогащения и переработки сложного по составу кольского минерального сырья, исследованы возможности производства в области строительных материалов.

В 1958-1960 гг. был осуществлён перевод всех лабораторий Кольского филиала в новый, отстроенный в сжатые сроки, научный городок. По инициативе А. В. Сидоренко на базе лабораторий горного дела и обогащения создаётся Горный институт, на базе отдела химической технологии и лаборатории технологии строительных материалов - Институт химии и технологии редких элементов и минерального сырья, в результате объединения разрозненных на территории Мурманской области научно-исследовательских подразделений различных центральных институтов - Полярный геофизический институт.

В 1952 г. А. В. Сидоренко защитил докторскую диссертацию на тему «К минералогии и геохимии континентальных толщ пустыни Кара-Кум». В 1953 г. за заслуги в разных областях геологии А. В. Сидоренко был избран членом-корреспондентом АН СССР. В том же году он образовал в Геологическом институте Кольского филиала АН СССР отдел четвертичной геологии и геоморфологии, которым непосредственно руководил до переезда в Москву в 1961 г. [1].

После переезда в Москву карьера Александра Васильевича Сидоренко развивалась очень успешно и 1966 году он стал академиком АН СССР. Помимо обширной научной деятельности (заведующий лабораторией литологии древних осадочно-метаморфизованных толщ Геологического института АН СССР, руководитель проекта «Металлогения докембрия» Международной программы геологической корреляции, вице-президент АН СССР, председатель секции наук о Земле АН СССР, директор лаборатории осадочных полезных ископаемых АН СССР, с 1979 года - создатель и директор Института литосферы АН СССР), А. В. Сидоренко занимал и видные государственные должности. В 1961-1962 гг. он являлся первым заместителем председателя Госкомитета Совмина РСФСР по координации научно-исследовательских работ, в 1962-1976 гг. был министром геологии и охраны недр СССР, председателем Государственного геологического комитета СССР, министром геологии СССР, в 1963-1975 гг. - руководителем Советской 
части СЭВ по геологии [2].

А.В. Сидоренко - лауреат Ленинской премии, награждён тремя орденами Ленина, орденами Трудового Красного Знамени и Красной Звезды, многими медалями СССР. Именем Сидоренко назван минерал сидоренкит $\mathrm{Na}_{3} \mathrm{Mn}\left(\mathrm{PO}_{4}\right)\left(\mathrm{CO}_{3}\right.$ ) (Хомяков А. П., Семенов Е. И., Казакова М. Е., Шумяцкая Н. Г., 1979). Его имя носит одна из центральных улиц города Апатиты.

Александр Васильевич уделял большое внимание физкультуре и спорту, сам бегал на лыжах и коньках, показывая личный пример работникам КФАН. Надо заметить, что А. В. Сидоренко приучил и работников администрации, и рядовых сотрудников к тому, что на катке можно не только бегать по кругу, но и обсуждать различные проблемы, решать наболевшие вопросы.

В марте 1982 г. в Геологическом институте КФАН СССР по инициативе А. В. Сидоренко сотрудники готовились к представительному международному совещанию по корам выветривания Балтийского щита. Громом с ясного неба было известие о трагической гибели Александра Васильевича в Египте. Совещание, конечно, не состоялось. Но память об Александре Васильевиче живёт. По стопам своего учителя идёт целая когорта его последователей - специалистов по биосфере раннего докембрия нашей планеты, по ранней геологической истории Земли, по древним континентальным отложениям и металлогении раннедокембрийских кор выветривания.

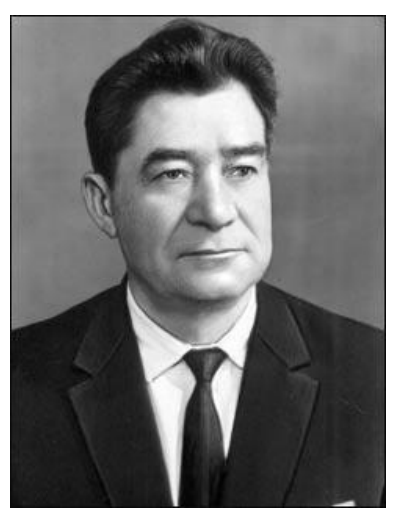

Точилин Митрофан Степанович
Митрофан Степанович Точилин (1910-1968), хотя формально и не учился в ВГУ (в 1936 г. он закончил геологический факультет Пермского госуниверситета), уже с 1939 г. работал в нашей «альма матер». С самого начала Великой Отечественной М. С. Точилин (так же, как и А. В. Сидоренко) добровольцем ушёл на фронт в составе Воронежского коммунистического полка, воевал в составе Западного, Закавказского, 2-го и 3-го Украинского фронтов, с 1945 г. - продолжил службу в составе советских войск в Венгрии и Австрии. М. С. Точилин награждён орденами Отечественной войны II степени и Красной звезды, медалями «За отвагу», «За освобождение Москвы», «За освобождение Сталинграда», «За взятие Будапешта», «За взятие Вены», «За победу над Германией», «За доблестный труд в Великой Отечественной войне». Сразу после войны М. С. Точилин вернулся на работу в Университет. С 1946 г. он являлся заведующим кафедрой, а затем и деканом геологического факультета ВГУ. Его роль в связи выпускников геолфака ВГУ тех лет с Кольским Заполярьем сложно переоценить.
С 1959 г. Митрофан Степанович (по совместительству с работой в ВГУ) по приглашению А.В. Сидоренко стал заведующим лабораторией региональной геологии, а впоследствии и заместителем директора ГИ КФАН СССР. М. С. Точилин работал в области региональной геологии, изучал вопросы первичной природы докембрийских пород Кольского полуострова, проблемы докембрийской и пост-протерозойской эволюции земной коры и закономерностей размещения в ней полезных ископаемых. Наиболее значимые научные достижения М. С. Точилина связаны с полосчатой железорудной формацией Кольского полуострова. Им детально были исследованы вопросы её генезиса, геологии и рудоносности в сравнении с аналогичными образованиями Кривого Рога и Курской магнитной аномалии.

Вот как писал об этих исследованиях один из его учеников - Н. М. Чернышов: «Вывод М. С. Точилина о генетической связи железистых кварцитов с подводным вулканизмом был фундаментальным вкладом в геологию рудных месторождений. Это было весьма убедительно доказано в его монографиях «Происхождение железистых кварцитов» (1963) и «Геология и генезис железистых руд Приимандровского района Кольского полуострова» (1964, совместно с П. М. Горяиновым) и сериях статей. Они получили высокую оценку, как среди отечественных геологов, так и за рубежом. Этот пример, кстати, показывает, сколь результативным оказалось его «научное совместительство» работы в разных железорудных регионах страны» [3].

Именем Митрофана Степановича назван минерал - точилинит $6 \mathrm{Fe}_{0,9} \mathrm{~S} \cdot 5(\mathrm{Mg}, \mathrm{Fe}++)(\mathrm{OH})_{2}$, открытый С. П. Молотковым в 1967 г. на Нижнемамонском сульфидном медно-никелевом месторождении.

М. С. Точилин вызвал на Кольский полуостров своего ученика, выпускника геолфака ВГУ 1959 г. Павла Михайловича Горяинова, ставшего его аспирантом. В результате изучения месторождений железистых кварцитов Кольского региона в свет вышел ряд их совместных статей и монография.

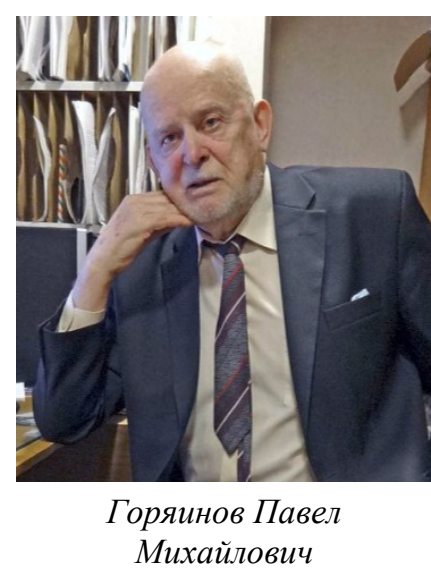

Вскоре Павел Михайлович Горяинов (1937-2019) успешно защитил по этой теме кандидатскую («Железистые кварциты Приимандровского района и их формационное положение», 1964), а позже и докторскую («Геология и генезис железисто-кремнистой формации Кольского полуострова», 1973) диссертацию, послужившую основой для одноименной монографии (1976).

Надо сказать, что Павел Михайлович являлся в то 
время самым молодым доктором наук во всем КФАН СССР! П. М. Горяинова отличала тяга ко всему новому, необычному, нетрадиционному. Неудивительно, что именно он, в рамках «железорудной группы» лаборатории Геологии рудных месторождений ГИ, впервые среди учёных КНЦ стал применять для изучения эволюции геологических объектов идеи синергетики - науки о процессах самоорганизации в термодинамически открытых системах с образованием «диссипативных структур». В последствии эти идеи были развиты им и его учениками в ряде основополагающих монографий («Структурно-вещественные парагенезисы железных руд докембрия Кольского полуострова», 1988; «Типы железорудных ансамблей и их геомагнитная систематика», 1990; «Введение в нелинейную геологию», 1996; «Самоорганизация минеральных систем», 2001; «Самоорганизация рудных комплексов. Синергетические принципы прогнозирования и поисков месторождений полезных ископаемых», 2009). В рамках развития этих идей, с середины 90-х годов ХХ века в ГИ КНЦ была создана специальная лаборатория синергетики минеральных систем, которую и возглавил П.М. Горяинов. Необходимо заметить, что Павел Михайлович подготовил себе достойную смену в виде многочисленных учеников и последователей, среди которых также есть выпускники геологического факультета ВГУ, о которых будет сказано ниже.

В 2016 году в честь П. М. Горяинова его учениками был назван минерал - горяиновит $\mathrm{Ca}_{2}\left(\mathrm{PO}_{4}\right) \mathrm{Cl}$, открытый на железнорудном месторождении Сахаваара в Швеции (авторы открытия - Г. Ю. Иванюк, В. Н. Яковенчук, Я. А. Пахомовский, Т. Л. Паникоровский, Н. Г. Коноплёва, А. В. Базай, В. Н. Бочаров, А. А. Антонов, Е. А. Селиванова). П.М. Горяинов является автором 11 книг и более 150 статей по вулканогенноосадочному рудообразованию и геологической самоорганизации [4].

Помимо весьма успешной научной деятельности, Павел Михайлович принимал активнейшее участие в спортивной жизни Геологического института, являясь многолетним лидером его шахматной сборной.

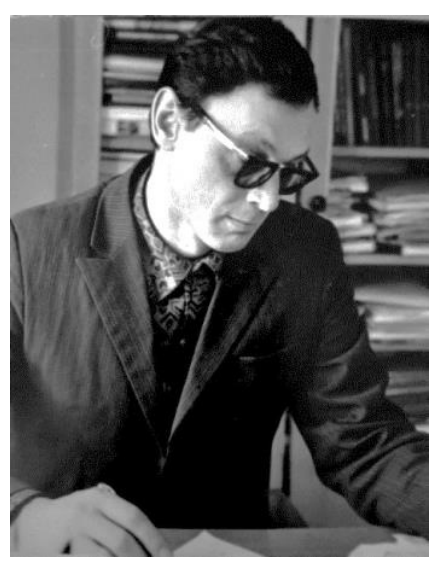

Припачкин Валентин Андреевич
Вслед за П. М. Горяиновым, в 1960 году в Апатиты приехал его однокурсник, Валентин Андреевич Припачкин. Но попал он не в группу М. С. Точилина, а в недавно открытую здесь лабораторию газов и битумов горных пород под руководством И.А. Петерсилье.

На долгие годы жизнь Валентина Андреевича Припачкина (19372010) оказалась связана с интересной работой - изучением газово-жидких включений в породах Хибинского щелочного массива. Работа эта завершилась написанием и успешной защитой в 1971 г. кандидатской диссертации на тему «Газовые компоненты щелочных горных пород Хибинского массива и закономерности их распределения». В 1984 г., после предложения из Президиума КФАН СССР, Валентин Андреевич согласился перейти на пост учёного секретаря Геологического института. С тех пор его карьера развивалась уже на поприще административной работы и с 1996 г. он стал заместителем директора Геологического института КНЦ по науке (некоторое время совмещая этот пост с должностью заведующего лабораторией газов и битумов горных пород). Одним из его важных достижений за время работы замдиректора ГИ КНЦ стало активное участие в создании Апатитского филиала Мурманского государственного технического университета (АФ МГТУ). На базе Геологического института была создана кафедра Полезных ископаемых АФ МГТУ, которую возглавил тогдашний директор ГИ КНЦ - Феликс Петрович Митрофанов, а В. А. Припачкин стал его заместителем. В дальнейшем Валентин Андреевич стал читать для студентов АФ МГТУ курс лекций «Буровые станки и бурение скважин» и проводить практику по этой дисциплине. С 1997 г. он стал профессором АФ МГТУ.

Необходимо отметить, что В. А. Припачкин помимо научной, административной и преподавательской деятельности, активно участвовал в спортивных мероприятиях, самодеятельности и общественной работе. В советское время он был бессменным редактором легендарной институтской стенгазеты «Геолог», затем - редактором научно-популярного журнала «Тиетта» и, наконец, главным редактором научного «Вестника КНЦ РАН». За период научной деятельности В. А. Припачкин опубликовал более 100 научных работ (из них - 4 монографии), он награждён двумя бронзовыми и серебряной медалями ВДНХ СССР (1970, 1976, 1986) орденом «За заслуги перед Отечеством» II степени (2002) [4].

Перечисляя наших выпускников, начинавших работать в Геологическом институте в конце 50-х начале 60-х годов XX века, можно уверенно говорить о настоящей «воронежской волне», нахлынувшей тогда на просторы северо-восточной части Балтийского щита. Помимо П. М. Горяинова, В. А. Припачкина это и В. Я Евзеров, С. В. Икорский, М. Т. Козлов, Л. Н. Латышев, А. В. Атаманов, П. К. Скуфьин, И. В. Давиденко. Можно смело утверждать, что именно выпускники той волны внесли наиболее заметный и значимый вклад в развитие заполярной науки, в становление Геологического института и всего Кольского филиала АН СССР - Кольского научного центра РАН. Поэтому - продолжим.

Евзеров Владимир Яковлевич - окончил геологический факультет Воронежского государственного университета в 1958 г. В этом же году начал свою трудовую деятельность в Геологическом институте КФАН СССР в должности заведующего лабораторией 


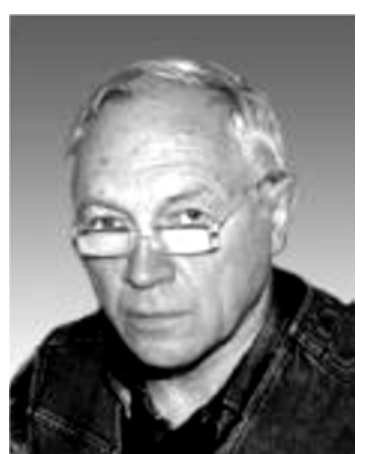

Евзеров Владимир Яковлевич геологии и минерагении кайнозойских отложений. С тех пор основной областью научных интересов В. Я. Евзерова являются геология и минерагения кайнозойских отложений и палеогеография кайнозоя. Владимир Яковлевич - крупный специалист в области изучения четвертичных отложений, приуроченных к ним полезных ископаемых и новейшей геодинамики территории Балтийского щита. Он внёс значимый вклад в теорию ледникового седиментогенеза, палеогеографию плейстоцена, минерагению россыпей и строительных материалов: разработал модели развития гляциоэвстатических трансгрессий, дегляциации Кольского региона, формирования россыпей на древних щитах, подвергавшихся покровным оледенениям, установил основные закономерности образования и размещения месторождений строительных материалов и россыпей, приуроченных к рыхлому покрову Кольского региона. Помимо научной ценности, работы В.Я. Евзерова имели и большое прикладное значение - он дал оценку ресурсов строительных материалов и россыпей алмазов, редких и благородных металлов, выявил критерии поисков указанных месторождений и научно обоснованные рекомендации по оптимизации поисково-разведочных работ, имеющие большое народно-хозяйственное значение. Поисково-разведочными работами, проведёнными по этим рекомендациям, расширена сырьевая база предприятий строительной индустрии Мурманской обл. Евзеров является одним из составителей международной карты «Четвертичные отложения Финляндии и Северо-Запада Российской Федерации и их сырьевые ресурсы», изданной в 1993 г. в Финляндии. Совместно с норвежскими учёными из университета Тромсё им собран обширный материал, необходимый для создания модели новейшей геодинамики северной части Балтийского щита.

В.Я. Евзеров успешно защитил кандидатскую («Геологическое строение, литологический состав и условия образования лопаритовых россыпей центральной части Кольского полуострова», 1968) и докторскую («Геология и минерагения четвертичных отложений северо-восточной части Балтийского щита», 2005) диссертации, является членом-корреспондентом МАНЭБ, под его руководством защищено две кандидатских диссертации. Он Автор более 150 научных работ в отечественной и зарубежной печати.

За успешную научную работу награждался дипломами и грамотами Президиума КНЦ РАН и Почётной грамотой РАН (1992) [4].

Икорский Серафим Вениаминович (1927-2016) окончил геологический факультет Воронежского государственного университета в 1957 г. После окончания Университета трудился в геологоразведочных

организациях Сибири и Воронежской области. В Геологическом институте КФАН/КНЦ работал с 1959 г. - младший научный сотрудник, заведующий лабораторией газов и битумов горных пород, с 1996 года - старший научный сотрудник лаборатории геохронологии и геохимии изотопов. Научные интересы С. В. Икорского были связаны с изучением геохимии газов и

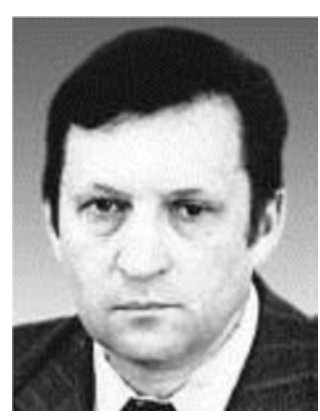

Икорский Серафим Вениаминович органического вещества изверженных и метаморфических пород, исследованием геохимии благородных газов в разрезе Кольской сверхглубокой скважины и палеозойских щелочных и щелочно-ультраосновных интрузивных комплексов Кольского полуострова. В рамках программы Прездиума РАН «Мировой океан» в содружестве с исследователями из других академических институтов Серафим Вениаминович изучал изотопию гелия и углеводородную составляющую в продуктах современной гидротермальной деятельности дна Атлантического океана. В 1967 г. он успешно защитил кандидатскую диссертацию на тему «Органическое вещество в породообразующих минералах Хибинского щелочного массива». С. В. Икорский являлся неутомимым изобретателем, имел целый ряд авторских свидетельств, в том числе на метод извлечения газов из пород и минералов путём дробления образцов в стеклянных ампулах (его широко применяют в изотопных исследованиях благородных газов). Он был награждён медалью «За трудовое отличие», бронзовой и серебряной медалями ВДНХ, является автором более 110 научных публикаций, в том числе 4 монографий [4].

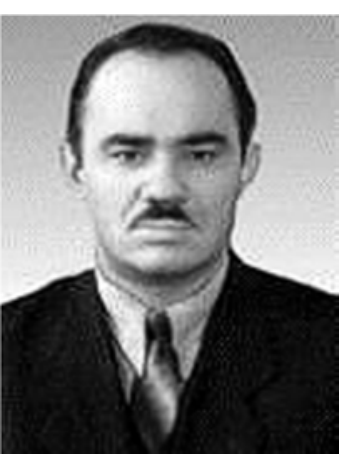

Козлов Михаил

Тихонович
Козлов Михаил Тихонович (1925-2003) - окончил геологический факультет Воронежского государственного университета в 1951 г., а затем и аспирантуру в 1958 г.. С 1951 по 1955 гг. работал старшим геологом в Горной экспедиции 1-го Главного геологического управления Тувинской АССР. Практическим результатом стало открытие Пертойского свинцового месторождения и зоны с перспективными медно-кобальтовыми рудопроявлениями. Затем работал старшим преподавателем ВГУ, в 1958-1959 гг. - начальником съёмочной партии по подготовке к изданию геологической карты Воронежского и Липецкого листов (1:200000). В 1959 г. защитил кандидатскую диссертацию на тему «Геология и малые интрузии западной окраины хребта Западный Танну-Ола».

В Геологическом институте КФАН СССР работал 
в период с 1959 по 1982 гг. в должностях младшего, а с 1970 г. - старшего научного сотрудника. Основное направление исследований Михаила Тихоновича было связано с изучением геологии (структуры, стратиграфии, тектоники и др.) района Федорово-Панских тундр, Имандра-Варзугской структуры и юговосточной части Кольского полуострова. Им проведено исследование сочленения Имандра-Варзугской зоны с Терско-Нотозерской и Центрально-Кольской зонами; составлена схема разрывной тектоники северо-восточной части Балтийского щита; разработаны оригинальные схемы стратиграфии и тектоники Имандра-Варзугской зоны. Его работы оказали существенное влияние на формирование представлений о генезисе и закономерностях размещения на территории Кольского п-ова рудной минерализации. М. Т. Козлов является автором более 40 публикаций, 18-ти производственных и научных отчётов. Михаил Тихонович был участником Великой Отечественной войны, за боевые заслуги награждён пятью медалями, в том числе «За отвагу», «За победу над Германией» и другими [4].

Михаил Тихонович, или легендарный «Мих-Тих», запомнился коллегам своим весёлым и жизнелюбивым нравом, его знаменитые «байки» до сих пор являются эталоном захватывающих геологических и около-геологических историй.

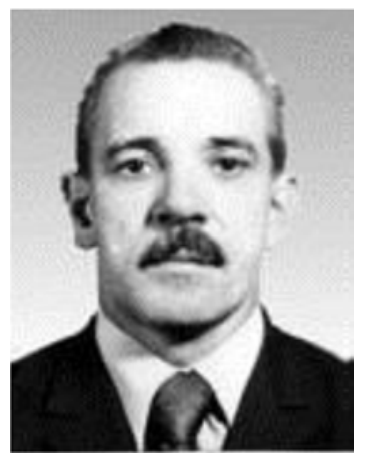

Латышев Лев Николаевич (1929-2004) - окончил геологический факультет ВГУ в 1956 г. В 1957-1958 гг. работал младшим, участковым и старшим геологом в Ловозерской геологоразведочной экспедиции. Результаты его исследований того периода изложены в отчётах по Ловозерскому плутону и Панским тундрам Кольского Латымев Лев Николаевич п-ова. В Геологическом институте КФАН/КНЦ Лев Николаевич работал с 1959 по 1990 гг. в должности - младшего научного, а с 1989 г. - в должности научного сотрудника. Л.Н. Латышев изучал тектонику, стратиграфию и вещественный состав пород южной части Лапладского гранулитового пояса (район Корва-тундры), архейские и нижнепротерозойские образования Мончегорского района и Прихибинья, а также нижнепротерозойские образования Имандра-Варзугской зоны. Материалы исследований Л. Н. Латышева за этот период изложены более чем в 30 публикациях и 12 научных отчётах [4].

Атаманов Анатолий Владимирович (1933-1990) - окончил геологический факультет Воронежского государственного университета, так же, как и Л. Н. Латышев, в 1956 г.. В период с 1956 по 1962 гг. Анатолий Владимирович тоже трудился в Ловозерской геологоразведочной экспедиции, где прошёл путь от простого геолога до главного геолога. В Геологиче- ском институте КФАН СССР/КНЦ РАН он работал с 1962 по 1990 гг. в должностях старшего инженера и младшего научного сотрудника. А. В. Атаманов занимался изучением геологического строения вермикулитовых месторождений и вопросами их систематики, а также проблемами образования кор выветривания в юго-западной части Мурманской области. Анатолий Владимирович - автор 12-ти статей и 4-х научных отчётов.

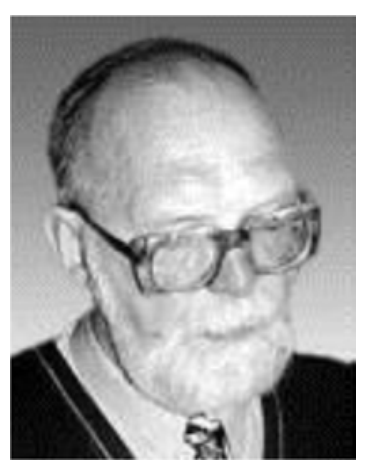

Скуфьин Петр

Константинович
Скуфьин Петр Константинович - окончил геологический факультет Воронежского государственного университета в 1960 г. С ноября 1960 г. П. К. Скуфьин начал обучение в очной аспирантуре Геологического института КФАН. За два полевых сезона в северо-западной части Кольского полуострова он собрал богатый материал по гнейсовым толщам кольской серии. С 1963 г.

П. К. Скуфьин работает в Геологическом институте в должностях младшего, старшего, а с 2002 г. - ведущего научного сотрудника. Круг научных интересов Петра Константиновича охватывал проблемы вулканологии и палеовулканологии, в частности - петрографии и геохимии вулканитов. Главными объектами его исследований являлись Печенгская, ИмандраВарзугская, Усть-Понойская и Пана-Куолаярвинская структуры. В 1963 г. П.К. Скуфьин защитил кандидатскую («Геология гнейсовых толщ северо-запада Кольского полуострова») а в 1998 г. - докторскую диссертацию на тему «Раннепротерозойские вулканогенные формации Печенгско-Варзугского пояса как индикаторы геодинамических режимов (северовосток Балтийского щита)».

В 1964 г. под руководством С. И. Зака и О. Б. Дудкина Петр Константинович проводил комплексные геологические работы на Сыннырском щелочном массиве в Бурятии, в результате чего было открыто крупное месторождение калиевого сырья. П. К. Скуфьин принимал активное участие в крупных научно-производственных проектах изучения Печенгской структуры, в частности, в работах 1968-1971 гг. по поискам медно-никелевых руд в малоисследованной Южнопеченгской структурно-формационной зоне. В 1974-1977 гг. П. К. Скуфьин осуществлял научное руководство при проведении комплексных геолого-геофизических и картировочных работ масштаба 1:50000 в ядерной части структуры; результа- 
том этих работ было составление первой палеовулканологической карты ядерной части Печенгской структуры масштаба 1:50000. В период с 1987 по 1995 гг. Петр Константинович проводил геолого-геохимические исследования в рамках научно-производственной программы ГДП-50, принимал участие в реализации норвежско-российского проекта «Зеленокаменный пояс Печенга-Пасвик-Полмак» (результатом этих исследований было составление первой НорвежскоРоссийской геологической карты пояса ПеченгаПолмак масштаба 1:100000, а также литологогеологической карты масштаба 1:25000 приграничной территории). Совместно с главным геологом Кольской сверхглубокой скважины СГ-3 Ю.Н. Яковлевым, П.К. Скуфьиным по керну сверхглубокой скважины СГ-3 был составлен детальный разрез вулканогенных свит сверхглубокой скважины, а также проведено изучение петрографии и геохимии вулканитов. Он автор и соавтор более 120 публикаций, является профессором КФ ПетрГУ и АФ МГТУ.

Кроме научной деятельности, Петр Константинович за время работы в Геологическом институте проявил себя как блестящий лектор-международник и популяризатор науки, умеющий заинтересовать самую взыскательную аудиторию.

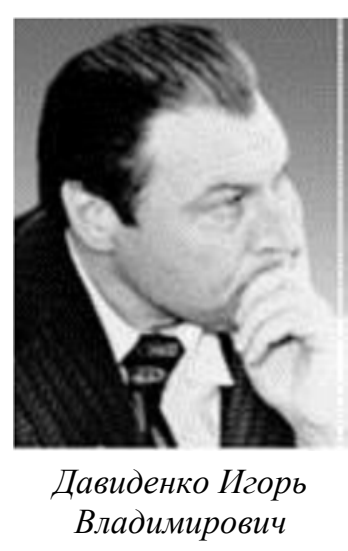

Давиденко Игорь Владимирович - окончил геологический факультет ВГУ в 1956 г. В Геологический институт КФАН был приглашён в 1966 г. после защиты в ВИМСе кандидатской диссертации по геологии и минералогии редкометалльных пегматитов Центрального Казахстана. В ГИ КФАН И. В. Давиденко работал до 1977 г. в должностях младшего и старшего научного сотрудника. В

1974 г. он защитил докторскую диссертацию на тему «Гранитные пегматиты докембрия», в 1979 г. совместно с П.М. Горяиновым разработал концепцию тектоно-кессонного эффекта как фактора динамической эволюции рудных систем. С 1978 г. Игорь Владимирович перешёл в НИИ «Зарубежгеология». Под его руководством и при непосредственном участии составлена карта полезных ископаемых Африки, получившая широкое признание в геологических и деловых кругах. И.В. Давиденко также руководил институтом по повышению квалификации Мингео России. На протяжении своей научно-геологической практики большое внимание и силы он уделял популяризации науки, в том числе и как лирический поэт, писательпублицист. И. В. Давиденко - автор более 170 научных работ в отечественной и зарубежной печати [4].

Игорь Владимирович увлекался не только геологической наукой, совместно с $Я$. А. Кеслером он является соавтором серии книг по истории цивилизации.
Особое место в его творчестве последних лет занимает работа над сценариями телевизионных фильмов («Десять лет, которые...», REN TV), а также над серией исторических эссе: «Санскрит по-русски», «Цивилизация» (Москва, 2001), «Ложные маяки истории» (Москва, 2002) и др.

Следующая волна выпускников геологического факультета ВГУ пришлась на 1970-е годы. Отличительной чертой того притока воронежских специалистов стало то, что помимо геологов (А. Е. Борисов) он принёс в Геологический институт немало геофизиков, практически составивших костяк и возглавивших лабораторию региональной геофизики. Определяющую роль здесь сыграли однокурсники - В.Н. Глазнев и А. Б. Раевский, пришедшие в заполярную науку после производства. А теперь - обо всех по порядку.

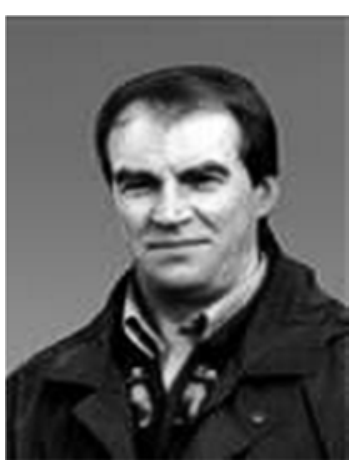

Борисов Анатолий Евгеньевич
Борисов Анатолий Евгеньевич - окончил геологический ф-т Воронежского государственного университета в 1973 г. В этом же году устроился на работу в ГИ КФАН, где работал до 1993 г. в должности младшего, а с 1993 по 2002 гг. - старшего научного сотрудника. Научные интересы А. Е. Борисова лежали в области вулканологии архея и протерозоя Кольского п-ова, а также геологии и металлогении никеленосных интрузивных комплексов. Он изучал вулканогенные и интрузивные комплексы Имандра-Варзугской, УстьПонойской, Куолаярвинской и Печенгской структур, а также Урагубско-Титовской зоны. Предложенная им модель чешуйчато-надвигового строения рудовмещающих толщ Печенги обозначила перспективы глубинного поиска сульфидных медно-никелевых руд и была использована в практической деятельности комбината «Печенганикель». В 1985 г. Анатолий Евгеньевич защитил кандидатскую диссертацию на тему «Палеовулканология меденосных вулканитов ИмандраВарзугской зоны». Научную деятельность Анатолий Евгеньевич успешно совмещал с работой геолога в ЗАО (позднее - ОАО) «Пана», непосредственно участвовал в открытии нескольких месторождений элементов платиновой группы (ЭПГ) в пределах ФедоровоПанского расслоенного мафит-ультрамафитового комплекса. А. Е. Борисов - автор 48-ми публикаций, из них 5-ти монографий, в том числе собственной - «Вулканизм и самородное медное оруденение в раннем протерозое Кольского полуострова» (1990) [4].

С 2002 г. А. Е. Борисов работал главным геологом Печенгской комплексной геологоразведочной экспедиции АО «Кольская ГМК», главным геологом ОАО КГИЛЦ, ныне является доцентом кафедры Геологии АФ МГТУ. В жизни Анатолий Евгеньевич - весёлый, компанейский человек, заядлый и удачливый рыбак, особенно на красную рыбу. 


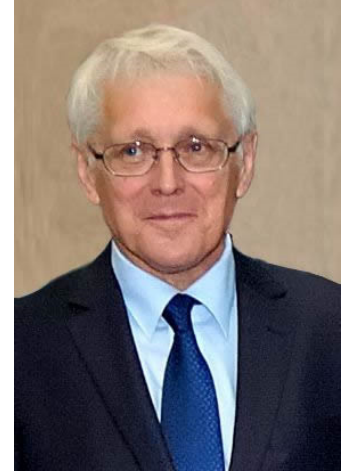

Глазнев Виктор Николаевич
Глазнев Виктор Николаевич - окончил геологический факультет ВГУ в 1972 г. По окончании университета работал в Мурманской геологоразведочной экспедиции (ныне - AO МГРЭ), где занимался скважинными геофизическими методами поисков медноникелевых месторождений. В Геологическом институте КФАН/КНЦ работал с 1976 по 2008 гг., с 1991 г. - в должности заведующего лабораторией региональной геофизики. Основным направлением научной деятельности В. Н. Глазнева являлась разработка теории и методологии комплексной интерпретации геофизических данных, а также теории стохастической интерпретации потенциальных полей. В рамках этого направления исследований Виктором Николаевичем были предложены принципиально новые методы решения комплексных обратных задач геофизики, учитывающие стохастические связи между параметрами среды в общей концепции совместного итерационного моделирования стационарных задач сейсмометрии, гравиметрии и геотермии. Практическая реализация этих новых методов интерпретации позволила В. Н. Глазневу совместно с коллегами по лаборатории выполнить построение комплексной трёхмерной модели литосферы Балтийского щита, включающей скоростную, плотностную, термическую, магнитную и, частично, геодинамическую модели среды. Исследования по данному направлению выполнялись в рамках международных проектов «Глубинная геология Балтийского щита» и «Свекалапко» Европейского научного фонда. В. Н. Глазнев участвовал в выполнении исследовательских работ по двум проектам ИНТАС и являлся руководителем четырёх инициативных проектов РФФИ, направленных на комплексное геофизическое изучение строения литосферы Фенноскандии в целом и детального строения земной коры ее восточной части (1995-2005). В.Н.Глазнев - кандидат («Применение теории корреляционных функций для анализа и интерпретации потенциальных полей», 1980), а с 2001 года - доктор физико-математических наук («Комплексные геофизические модели литосферы Фенноскандии»).

Виктор Николаевич - автор более 150 научных работ в отечественной и зарубежной печати. До 2008 года он являлся профессором КФ ПетрГУ и АФ МГТУ, где читал курс общей физики и ряд дисциплин геофизической специальности. С 2008 г. В. Н. Глазнев - заведующий кафедрой геофизики Воронежского госуниверситета [4].

Раевский Алексей Борисович - как и В. Н. Глазнев, окончил геологический факультет Воронежского государственного университета в 1972 г..
После службы в армии и работы в Мурманской ГРЭ, с 1976 г. работает в Геологическом институте КФАН/КНЦ в должностях инженера, младшего научного, с 1999 г. - старшего научного сотрудника, с 2008 г. - заведующего лабораторией региональной геофизики. Кандидат физико-математических наук («Применение линейных трансформаций при гравитационном моделировании верхней части земной коры на кристаллических щитах (на примере западного района Кольского полуострова)», 1985). Алексей Борисович является специалистом в области интерпретации потенциальных геофизических полей, он участвовал в составлении алгоритмов и программ для решения прямых и обратных задач гравиметрии в трёхмерной постановке и на сферической Земле. А. Б. Раевский также занимался разработкой моделей глубинного строения земной коры и мантии для территории восточной части Балтийского щита. Результаты этой работы в составе творческого коллектива отмечены дипломом КНЦ (1996), а также научными публикациями, в том числе в международных изданиях [4].

С 2008 по 2013 гг. А. Б. Раевский являлся активным участником проекта по изучению Серповидной складки в пределах Кейвского террейна. В результате этих работ был разработан метод решения обратной задачи магниторазведки для модуля геомагнитного поля. Алексей Борисович занимается преподавательской деятельностью - он доцент кафедры геологии и геофизики горнотехнического ф-та КФ ПетрГУ.

В 1970-е годы в лабораторию Региональной геофизики пришли ещё две выпускницы геолфака ВГУ Валентина Тихоновна Ионкис и Людмила Григорьевна Осипенко.

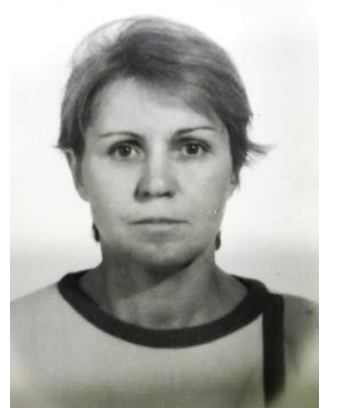

Ионкис Валентина Тихоновна
Ионкис (Кулигина) Валентина Тихоновна по окончании геологического факультета Воронежского госуниверситета (1970 г.) в 1970-72 гг. трудилась в Дальневосточном геолуправлении, в 1972 г. - на кафедре геофизики ВГУ. В Геологическом институте работала в период с 1973 по 1992 гг. (инженер, младший научный сотрудник). Валентина Тихоновна занималась изучением глубинного строения земной коры Кольского полуострова методами сейсмозондирования с использованием промышленных взрывов, внедряла машинные методы интерпретации сейсмических данных. Она активно участвовала в спортивной жизни института - выступала на различных соревнованиях по горным и равнинным лыжам. 


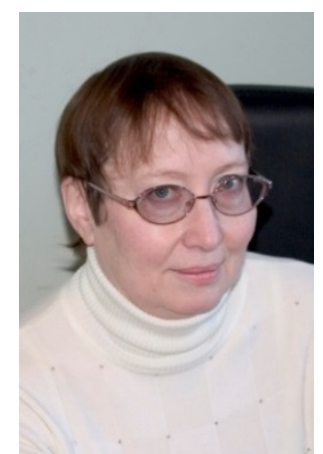

Осипенко Людмила

Григорьевна
Осипенко Людмила Григорьевна - окончила геологический факультет Воронежского госуниверситета в 1970 г. по специальности «геофизические методы поисков и разведки месторождений полезных ископаемых». После окончания работала в производственных организациях Дальнего востока. Начиная с 1975 г. работает в лаборатории региональной геофизики Геологического института в должностях старшего лаборанта, старшего инженера, младшего научного сотрудника. Основное направление работ, выполняемых Л. Г. Осипенко, связано со сбором, систематизацией, обобщением и анализом региональных геофизических данных по территории Балтийского щита и его обрамления, включая Баренцевоморский и Тимано-Печорский регионы. В ее обязанности входит создание и поддержка информационных баз данных по геофизике Балтийского щита в целом и Кольского региона в частности. За время работы Людмила Григорьевна зарекомендовала себя высококвалифицированным специалистом геофизиком в области региональной геофизики и петрофизики горных пород.

В конце 1970-х геофизическое направление пополнилось еще одним выпускником ВГУ - Сергеем Викторовичем Зубаревым.

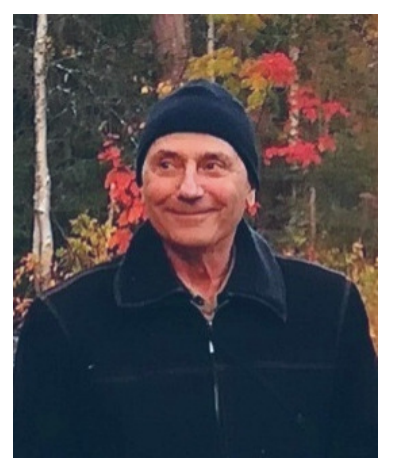

Зубарев Сергей

Викторович

Зубарев Сергей Викторович - окончил геологический факультет Воронежского госуниверситета в 1974 г. В период с 1979 по 1989 гг. работал в Геологическом институте КФАН в должности инженера, старшего инженера в лаборатории региональной геофизики, где занимался глубинным сейсмическим зондированием с использованием промышленных взрывов. С 1989 по 1996 гг. С. В. Зубарев работал в Горном институте КНЦ РАН в должности научного сотрудника и занимался проблемой снижения сейсмического воздействия массовых взрывов на здания и сооружения.

В 80-е годы ХХ века в ГИ КФАН СССР пришла очередная группа выпускников-геологов из ВГУ.

В 1980 г. в аспирантуру Геологического института поступили супруги Михаил Михайлович и Галина Валентиновна Козловы. Оба они закончили геологический факультет ВГУ в 1975 г., оба затем работали в Тувинской ГРЭ (г. Кызыл). В дальнейшем их судьба в ГИ КФАН/КНЦ сложилась по-разному.

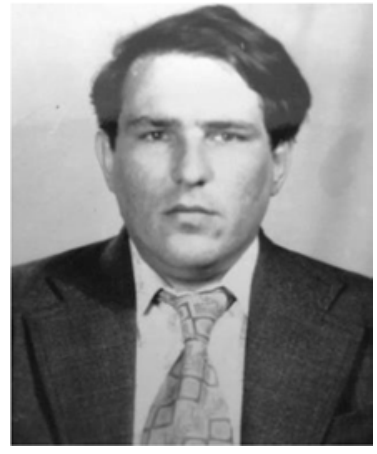

Козлов Михаил

Михайлович

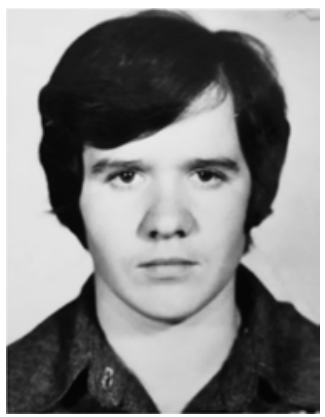

Козлова Галина

Валентиновна

Козлов Михаил Михайлович проработал здесь до 1983 г. (аспирантом, затем инженером), занимаясь исследованием структуры рудного поля юго-западной части Хибинского массива. Потом он из института уволился, трудился в геологоразведочных экспедициях Мурманской области, а в последние годы живет и работает в Норвегии.

Козлова Галина Валентиновна после учёбы в очной аспирантуре, с 1983 по 1991 гг. работала в лаборатории геологии рудных месторождений (старший лаборант, младший научный сотрудник), где сначала занималась изучением геологии и генезиса железорудных месторождений, а затем - медно-никелевых месторождений Печенгского рудного поля.

Чуть позже, по приглашению П. М. Горяинова в Геологический институт КФАН СССР приехал Павел Валентинович Припачкин - выпускник геолфака ВГУ 1984 г.

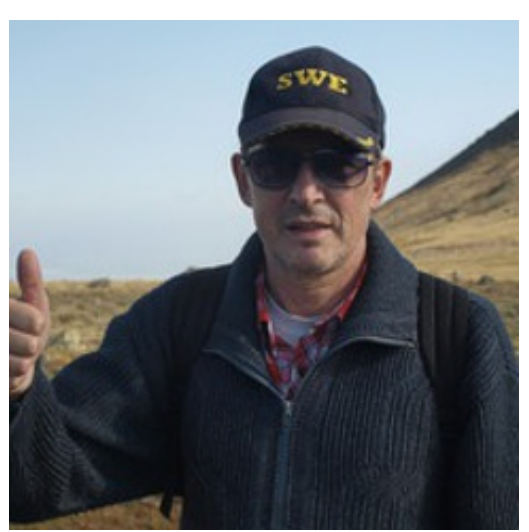

Припачкин Павел Валентинович
В Геологическом институте

Павел Валентинович Припачкин влился в «железорудную группу» лаборатории Геологии рудных месторождений, изучающую месторождения железистых кварцитов. Результатом этих исследований под руководством П. М. Горяинова стала успешная защита в 1994 г. кандидатской диссертации на тему «Количественная оценка структурно-вещественных комплексов Приимандровского района Кольского полуострова». В 1995 г. П. В. Припачкин перешёл во вновь образованную лабораторию платинометалльного рудогенеза, где стал заниматься расслоенными ультрамафит-мафитовыми интрузиями и их комплексным оруденением. Параллельно по совместительству он 8 лет отработал геологом в созданном при институте ОАО «Пана», занимающимся поисково-разведочными работами на ЭПГ. П. В. Припачкин причастен к от- 
крытию нескольких месторождений ЭПГ в пределах Федорово-Панского и Мончегорского расслоенных комплексов, он автор и соавтор многочисленных научных статей по геологии, минералогии, геохимии и петрологии расслоенных интрузий Кольского пояса, регулярно проводит по этим объектам экскурсии для отечественных и зарубежных геологов, соавтор нескольких путеводителей. Эту работу он совмещает с успешной преподавательской деятельностью в двух ВУЗах - МАГУ и АФ МГТУ, где читает несколько курсов лекций («Буровые станки и бурение скважин», «Основы нефтегазового дела», «Полезные ископаемые Арктики»), а также является руководителем учебных практик, курсовых и дипломных работ студентов. П. В. Припачкин активно занимается популяризацией геологической науки - он читает лекции в рамках работы городского научного лектория, а в 2018 г. являлся главным редактором институтского научно-популярного журнала «Тиетта».

В конце 1980-х в ГИ КФАН СССР устроился ещё один выпускник ВГУ - Андрей Юрьевич Барков.

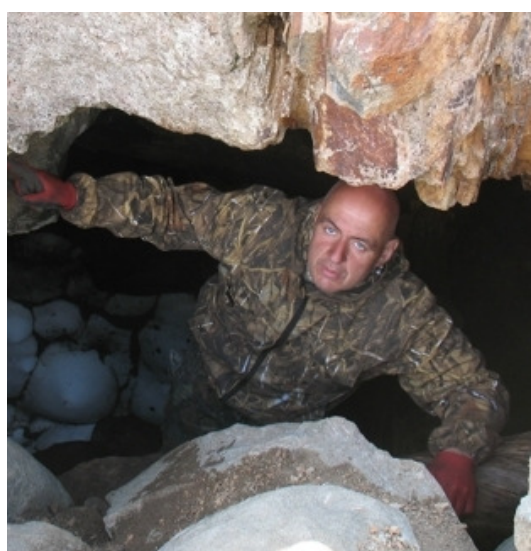

Барков Андрей Юрьевич
Барков Андрей Юрьевич окончил геологический факультет ВГУ в 1986 г. В Геологическом институте КНЦ РАН работал с 1986 по 2000 гг. в должности научного сотрудника лаборатории минералогии. А. Ю. Барков занимался расслоенными интрузиями Олангской группы - их минералогией, петрохимией и геохимией примесных элементов. Им было проведено датирование этих интрузий, предложены модели петрологии массивов и рудогенеза, намечены типоморфные минералы и геохимические ассоциации. А. Ю. Барковым открыты и обнаружены некоторые новые для региона минералы, он участвовал в изучении платинометалльной минерализации массивов Бураковский, Имандровский, г. Генеральская. В 1992 г. А. Ю. Барков успешно защитил кандидатскую диссертацию на тему «Петролого-геохимические особенности платиноносных расслоенных интрузий Луккулайсваара и Кивакка, Северная Карелия», а в 1997 - международную степень Ph.D. (Geology and mineralogy) в Университете Оулу, Финляндия [4].

Научные исследования Андрея Юрьевича получили широкое международное признание. В течение двенадцати лет он проводил исследовательскую работу в университетах Канады и западной Европы. Сфера основных научных интересов А. Ю. Баркова включает исследования в области минералогии, геохимии,

петро- и рудогенеза мафит-ультрамафитовых комплексов и связанных с ними зон сульфидной медноникелевой, хромитовой и платинометалльной минерализации, а также россыпных рудопроявлений.

В 2012 г. А. Ю. Барков успешно защитил в ИГЕМ РАН докторскую диссертацию на тему «Зональность, вариации состава, механизмы замещения элементов и ассоциации редких рудных минералов из мафитультрамафитовых комплексов». В настоящее время Андрей Юрьевич - главный научный сотрудник и заведующий научно-исследовательской лабораторией «промышленная и рудная минералогия» Череповецкого государственного университета. Он является автором около ста статей, опубликованных преимущественно в международных научных журналах, а также входит в состав редколлегии международного научного журнала «Minerals».

В 1990-х - начале 2000-х состоялся, к сожалению, последний на сегодняшний день приток выпускников геологического факультета ВГУ в Геологический институт КНЦ РАН. Впрочем, это касается не только ВГУ, но и других крупных ВУЗов, находящихся за пределами Кольского региона. В значительной степени это связано с переориентацией институтов КНЦ на местные кадры в результате открытия Апатитского филиала Мурманского государственного технического университета (АФ МГТУ). В Геологический институт стали привлекаться выпускники кафедры Геологии АФ МГТУ, как правило, проживающие в Мурманской области. Но - вернёмся к выпускникам ВГУ.

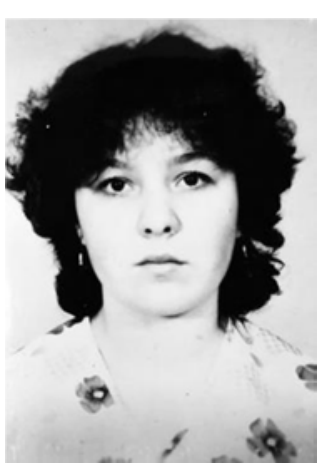

Попова Лариса Ивановна

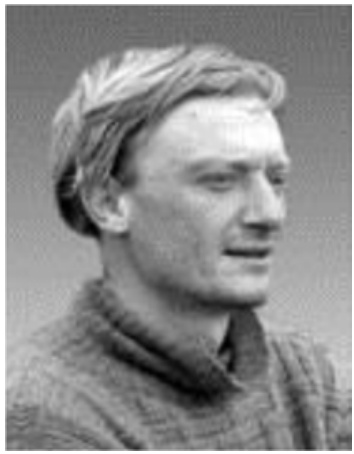

Вурсий Геннадий Леонтьевич
Попова Лариса Ивановна - окончила геологический факультет Воронежского госуниверситета в 1993 г. В период 1993 по 1996 гг. прошла обучение в очной аспирантуре при Геологическом институте КНЦ РАН, работала в лаборатории платинометалльного рудогенеза, где занималась изучением метаморфических преобразований пород дифференцированных интрузий.

Вурсий Геннадий Леонтьевич - окончил геологический факультет Воронежского государственного университета в 1997 г. С этого же года начал трудовую деятельность в Геологическом институте КНЦ РАН в должности научного сотрудника. Областью профессиональных интересов Геннадия Леонтьевича являлась петрология расслоенных интрузий и минерагения благородных элементов. С 1997 
по 2001 гг. он трудился в лаборатории геологии и экономики новых видов минерального сырья, где занимался изучением закономерностей внутреннего строения и формирования гипербазит-базитов плутона Гремяха-Вырмес. По результатам этих исследований Г. Л. Вурсий в 2001 году защитил кандидатскую диссертацию на тему «Геология и петрология гипербазит-базитов плутона Гремяха-Вырмес (Кольский полуостров)». С 2001 по 2005 гг. Г. Л. Вурсий работал в лаборатории платинометалльного рудогенеза и занимался изучением геологического строения и петрологии расслоенных интрузивов Кольского полуострова, поисками комплексных платинометалльных руд, исследовал закономерности их локализации и вещественный состав. Г. Л. Вурсий является автором 27 научных работ [4].

С 2001 г. он совмещал научную деятельность в Геологическом институте с работой в ОАО «Пана». Как и другие сотрудники ОАО «Пана», Геннадий Леонтьевич внёс большой вклад в открытие ряда ЭПГ месторождений Федорово-Панского расслоенного мафит-ультрамафитового комплекса. После Геологического института Г. Л. Вурсий успешно продолжает карьеру в крупных геологоразведочных компаниях ООО «Баррик Рисорсес» (геолог проекта на проведение геологоразведочных работ на золоторудных рудопроявлениях Забайкалья и Хабаровского края); Руссдрагмет - «Highland Gold» (ведущий геолог), 3АО «Полюс» (ведущий геолог), «N-Mining Limited» (главный геолог), ПАО «Полюс» (главный геолог проекта «Сухой Лог» - «СЛ Золото»).

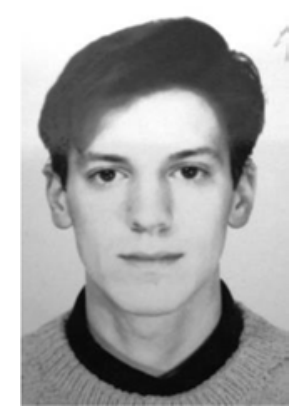

Ященко Юрий

Александрович гомологов на поверхности.

В 1998 г. в ГИ КНЦ пришёл выпускник геологического факультета ВГУ этого же года Юрий Александрович Ященко. С 1998 по 2002 годы Юрий Александрович Ященко работал в лаборатории геологии и геохимии протолитов раннедокембрийских комплексов древних щитов, где занимался изучением вещественного состава пород и минералов в Кольской сверхглубокой скважине и их

Наконец, в середине 2000-х, в Геологическом институте КНЦ РАН появился ещё один выпускник геологического факультета Воронежского госуниверситета 2005 г. - Андрей Олегович Калашников.

Еще будучи студентом, Андрей Олегович Калашников начал применять нетрадиционные методы к оценке структур горных пород в своей дипломной работе. На почве обсуждения новых подходов к изучению геологических объектов А. О. Калашников познакомился с основателем лаборатории синергетики минеральных систем ГИ КНЦ РАН профессором Павлом Михайловичем Горяиновым, который пригласил студента-дипломника в аспирантуру. Приглашение было принято, и с 2005 г. Андрей Олегович работает в этой лаборатории в должностях младшего научного, научного, а с 2018 г. - старшего научного сотрудника. $\mathrm{C}$ самого начала своей работы А. О. Калашников продолжает развивать и творчески

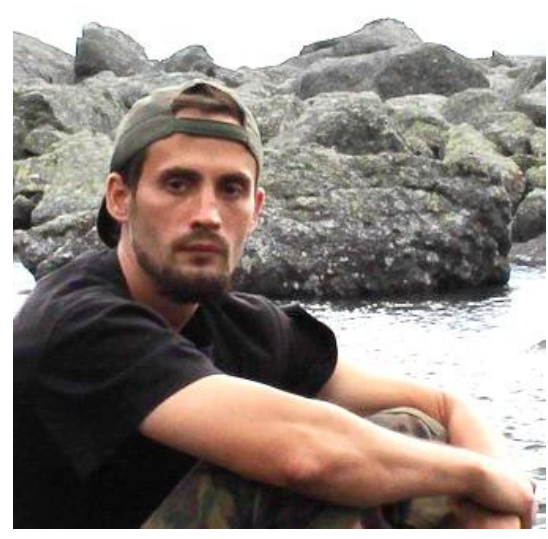

Калашников Андрей Олегович совершенство-

вать подходы П. М. Горяинова в области поисков и прогноза рудных объектов, основанные на теории самоорганизации. Главными объектами исследований в этом направлении являются эндогенные месторождения Кольского региона и России. В 2009 г. по результатам этих работ А. О. Калашников успешно защитил кандидатскую диссертацию в Воронежском университете на тему «Структурно-вещественная упорядоченность геологических объектов как поисковый признак эндогенных месторождений».

С 2011 г. А. О. Калашников занимается решением задач повышения комплексности использования руд на основе уточнения и предсказания их свойств in situ. В рамках этого направления им был разработан ряд методов предсказания технологических свойств руд по их химическому составу; методология геометаллургического (минералого-технологического) моделирования месторождений на основе тонкого анализа минерального вещества; методология автоматического 3D геологического картирования. Поскольку исследование руд неотделимо от проблем рудогенеза, фундаментальным результатом этих работ стала новая модель образования Ковдорского фоскориткарбонатитового комплекса и цирконий-редкоземельного оруденения Кейвских щелочных гранитов (Мурманская область). Результаты его работ отражены в многочисленных публикациях, в том числе - в ведущих международных журналах (около 20 статей) и монографии. А. О. Калашников активно внедряет свои разработки в производство - сотрудничает с крупнейшими горно-геологическими предприятиями региона. Андрей Олегович - финалист «Конкурса русских инноваций» (проект «Технология прогнознопоисковых работ, основанная на принципах теории самоорганизации», 2008), лауреат премии РОСГЕОРоснедра в области науки и инновационных технологий в геологическом изучении недр России (проект «Разработка синергетических принципов геологического анализа (фундаментальные и прикладные аспекты)», 2011), является членом Society of Economic Geologists (США).

Таким образом, можно уверенно констатировать, что практически со дня основания Кольского филиала 
Академии наук и до наших дней - выпускники геологического факультета Воронежского университета играли в заполярной науке далеко не последние роли. Более того, такие люди как А. В. Сидоренко, были настоящими лидерами, возглавлявшими и КФАН СССР, и первый его институт - ГИ КФАН. В руководстве ГИ КФАН/КНЦ затем работали М. С. Точилин, и ещё один выпускник ВГУ - В. А. Припачкин.

М. С. Точилин положил начало научному изучению железисто-кремнистой формации Кольского региона, которое затем успешно продолжил его ученик П. М. Горяинов, в свою очередь давший жизнь синергетике и возглавивший лабораторию синергетики минеральных систем. В.Я. Евзеров долгое время возглавлял лабораторию геологии и минерагении кайнозойских отложений, В. Н. Глазнев и А. Б. Раевский в разные годы руководили лабораторий Региональной геофизики, В. А. Припачкин и С. В. Икорский - лабораторией газов и битумов горных пород.

А. В. Сидоренко был академиком, М. С. Точилин, П. М. Горяинов, В. Я. Евзеров, П. К. Скуфьин, И. В. Давиденко, В. Н. Глазнев, А. Ю. Барков - стали докторами наук, подавляющее большинство остальных выпускников геолфака ВГУ, работавших и работаю- щих в ГИ КНЦ - кандидатами наук. Многие из наших выпускников причастны к открытиям различных месторождений полезных ископаемых, именами некоторых из них названы минералы, они развивают нетрадиционные подходы в геологии, являются участниками крупных научных форумов, имеют достаточное количество научных публикаций в ведущих мировых изданиях. Все они, безусловно, с честью несли и несут высокое звание - выпускник геологического факультета Воронежского государственного университета.

\section{ЛИТЕРАТУРА}

1. Архивы Российской академии наук [Электронный ресурс]. - Режим доступа: http://isaran.ru/?guid=54C85DDA9452-50D6-2BF6-0BD766A81A82\&q=ru/person (дата обращения 25.11.2019).

2. Википедия [Электронный ресурс] - Режим доступа: https://ru.wikipedia.org/wiki/ (дата обращения 25.11.2019).

3. Чернышов, Н. М. «ВОИН, ПЕДАГОГ, УЧЕНЫЙ» ТОЧИЛИН Митрофан Степанович (1910-1968) / Н. М Чернышов // Вестник Воронеж. гос. ун-та. Сер.: Геология. - 2010. - №2. - C. 328-321

4. Ученые Кольского научного центра (1930-2005). - Апатиты: Изд-во КНЦ РАН, 2006. - 89 с.

Geological Institute of the Kola Science Center of the Russian Academy of Sciences (GI KSC RAS), Apatity демии наук (ГИ КНЦ РАН), г. Anатить

Припачкин Павел Валентинович, кандидат геологоминералогических наук, стариий научный сотрудник лаборатории минерагении Арктики E-mail:paul@goeksc.apatity.ru

Скуфьин Петр Константинович, доктор геологоминералогических наук, ведуший научный сотрудник лаборатории минерагении Арктики

E-mail: skuf@geoksc.apatity.ru
Pripachkin P. V., Candidate of Geological and Mineralogical Sciences, Senior Researcher, Laboratory of the Arctic Minerageny

E-mail:paul@goeksc.apatity.ru

Skufin P. K., Doctor of Geological and Mineralogical Sciences, Lead Researcher, Laboratory of the Arctic Minerageny

E-mail: skuf@geoksc.apatity.ru 